\title{
How Verbal Variety Kills Comprehension
} COMMUNICATION CORNER No. 35

\author{
by Philip Yaffe
}

\section{Editor's Introduction}

Each "Communication Corner" essay is self-contained; however, they build on each other. For best results, before reading this essay and doing the exercise, go to the first essay "How an Ugly Duckling Became a Swan," then read each succeeding essay.

The purpose of expository (non-fiction) writing and speaking is usually to inform or instruct. To do either successfully, you must present your ideas more than once. Otherwise, people who read it or hear it, even if they completely understand it at the moment, over time (often a very short time) will either confuse it or forget it. Presenting information and ideas more than once is not simply a matter of saying the same things the same way two or three times. It is more subtle than that. 


\title{
How Verbal Variety Kills Comprehension
}

\author{
COMMUNICATION CORNER No. 35
}

\section{by Philip Yaffe}

As any teacher knows, saying something once is tantamount to not saying it at all. People may recognize an idea the first time it is presented, but they almost never assimilate it and make it their own until it is repeated.

Nevertheless, in expository (non-fiction) writing, repetition seems to be a no-no. The purpose of expository writing is generally to inform or instruct; yet young writers are often enjoined to avoid repetition at all costs.

I became aware of this bizarre and detrimental phenomenon by living in Europe and learning other languages. I have been a resident of Belgium since 1974. I fluently speak French, and have working knowledge of Dutch, German, and Spanish.

Everyone I know who writes documents in these languages will do just about anything to avoid repeating a word. It seems that when they were in school, they were told that if they repeated a word, their hands would be cut off. Verbal variety was a prime virtue; word repetition a prime $\sin$.

Growing up in California, I don't recall this taboo being pounded into my head the way it seems to be here in Europe, but maybe I wasn't paying attention. In any event, while the advice is sound, the way people have interpreted it wrong.

Intentionally used, repetition improves rather than damages writing. The keyword is "intentionally." As in teaching-expository writing is a kind of teaching-saying something once seldom gets the point across. The solution, we are told, is to say it several times, but in different ways. However, constantly changing vocabulary for the sake of variety more often than not leads to confusion, rather than clarity. Consider the following:

A. I saw a big dog. I am afraid of big dogs, so I cautiously moved away.

B. I saw a big dog. I am afraid of large canines, so I cautiously moved away.

Changing "big dogs" to "large canines" adds nothing to the text, and in fact detracts from it. This of course is a made-up example, but I have seen many real examples equally ridiculous. 
Consistently using the same terminology can advance your argument while mixing terminology can hobble it. This is true both in expository (non-fiction) and creative (fiction) writing.

But you don't have to take my word for it. Here are excerpts from two of the finest pieces of writing anyone has ever produced: The Gettysburg Address by Abraham Lincoln and The Marc Antony Soliloquy by William Shakespeare. One is fiction, the other non-fiction. Both make undeniably effective use of repetition.

\section{The Gettysburg Address}

This speech was delivered by President Abraham Lincoln at Gettysburg, Pennsylvania on November 19, 1863 to mark a pivotal victory in the American Civil War. The repetitions are indicated by a double asterisk (**).

"Four score and seven years ago our fathers brought forth on this continent a new nation, conceived in liberty and dedicated to the proposition that all men are created equal.

"Now we are engaged in a great civil war, testing whether that **nation-or any $* *$ nation so ${ }^{* *}$ conceived and so ${ }^{* *}$ dedicated-can long endure. We are met on a great battlefield of that $* *$ war. We have come to dedicate a portion of that $* *$ field as a final resting place for those who here gave their lives that that $* *$ nation might $* *$ live.

"It is altogether fitting and proper that we should do this. But in a larger sense, we cannot **dedicate, we cannot consecrate, we cannot hallow this ground. The brave men, living and dead, who struggled here have **consecrated it far above our poor power to add or detract.

"The world will little note, nor long remember, what we say here, but it can never forget what they did here. It is for us the living, rather, to be **dedicated here to the unfinished work which they who fought here have thus far so nobly advanced.

"It is rather for us to be here ${ }^{* *}$ dedicated to the great task remaining before us. That from these honored dead we take increased devotion to that cause for which they gave the last full measure of ${ }^{* *}$ devotion. That we here highly resolve that these dead shall not have died in vain. That this nation, under God, shall have a new birth of freedom. And that government of the people, by $* *$ the people, for $* *$ the people, shall not perish from the earth."

Stirring stuff, isn't it?

Now let's look at just the first two paragraphs to see what it might have looked like if Lincoln had avoided repetition. 
"Four score and seven years ago our fathers brought forth on this continent a new nation, conceived in liberty and dedicated to the proposition that all men are created equal.

"Now we are engaged in a great civil war, testing whether that country-or any nationstate founded and pledged in this way-can long endure. We are met on a great battlefield of that conflict. We have come to dedicate a portion of this patch of ground as a final resting place for those who here gave their lives that this homeland might continue to exist...."

Hardly the same, is it?

\section{Marc Antony Soliloquy}

This speech was delivered by Marc Antony in Shakespeare's play "The Tragedy of Julius Caesar." Once again, the repetitions are marked by a double asterisk (**).

"Friends, Romans, countrymen, lend me your ears. I come to bury Caesar, not to praise him. The evil that men do lives after them; the good is oft interred with their bones. So let it be with Caesar.

"The noble Brutus hath told you Caesar was ambitious. If it were so, it was a grievous fault, and ${ }^{* *}$ grievously hath Caesar answer'd it. Here, under leave of Brutus and the rest-for Brutus is an **honorable man; so are they all, all **honorable men-come I to speak in Caesar's funeral.

"He was my friend, faithful and just to me. But Brutus says he was **ambitious, and Brutus is an **honorable man.

"He hath brought many captives home to Rome, whose ransoms did the general coffers fill. Did this in Caesar seem **ambitious? When that the poor have cried, Caesar hath wept. **Ambition should be made of sterner stuff. Yet Brutus says he was **ambitious, and Brutus is an **honorable man."

The soliloquy continues. Through repetition, the crowd comes to equate Caesar with "saint," Brutus with "murderer," and "honorable" with "dishonorable." The crowd riots and overthrows the junta, which is led by Brutus, only days before had assassinated Caesar to public acclaim.

\section{The Bicentennial Man}


It may be argued that the Marc Antony Soliloquy is not "true fiction," because it is a speech within a play and meant to sound realistic. Much of fiction is description, where verbal variety is virtually obligatory.

Here is a descriptive passage from "The Bicentennial Man," a collection of short stories by Isaac Asimov, a master of both creative and expository writing. Once again, the repetitions are marked with a double asterisk. Try to imagine this passage if each repetition were changed to something else.

The fact that JN-5 was a radically new type of robot, quite different from anything ever built before, was distressing.

**The fact that JN-5 was a prototype, the first after four earlier attempts ever placed in the field, was more distressing.

**The fact that JN-5 had apparently accomplished something of incalculably importance-and that now might be forever gone-placed the distress utterly beyond words.

It is not my purpose to argue that verbal variety isn't important, only that blindly changing words to avoid repetition can be counterproductive.

So how can you know when and when not to vary vocabulary?

As in any intellectual endeavor, in writing, if you know why you are doing something, rather than simply because it is a rule, chances are you will do it better. The key consideration is: Will changing a word advance the purpose of my text? If yes, then change it. If not, don't.

Early in his career, Pablo Picasso was a classical painter, perhaps on a par with Rubens and Rembrandt. One day he was asked, "Señor Picasso, if you can paint like that, why do you do this almost childish, abstract stuff?" He is reported to have replied, "You need to understand the rules to know how to creatively break them."

Go, and be creative.

\section{About the Author}

Philip Yaffe was born in Boston, Massachusetts, in 1942 and grew up in Los Angeles, where he graduated from the University of California with a degree in mathematics and physics. In his senior year, he was also editor-in-chief of the Daily Bruin, UCLA's daily student newspaper. He has more than 40 years of experience in journalism and international marketing communication. At various points in his career, he has been a teacher of journalism, a 
reporter/feature writer with The Wall Street Journal, an account executive with a major international press relations agency, European marketing communication director with two major international companies, and a founding partner of a specialized marketing communication agency in Brussels, Belgium, where he has lived since 1974. He is the author of more than 30 books, which can be found easily in Amazon Kindle.

DOI: $10.1145 / 3462743$ 